\title{
Labour market and labour market policies during great recession: the case of Estonia
}

\author{
Raul Eamets
}

Correspondence:

raul.eamets@ut.ee

Faculty of Economics and Business

Administration Narva mnt. 4,

University of Tartu, Tartu 51009,

Estonia

\section{Springer}

\begin{abstract}
The purpose of the paper is to analyse how labour market and labour market institutions reacted during recent crises. In early 1990s Estonia introduced a set of rather unique policy options like currency board as a ground for monetary policy, low taxes, open foreign trade policy, low public sector debts, annually balanced state budget etc. These measures caused very limited options to implement both monetary and fiscal policy. Macroeconomic adjustment will take place in such situation through the labour market. In the case of Estonia, we can observe a very high labour market flexibility, which played a crucial role in recent economic recession. The measures taken included a reduction of nominal wages, working hours and redundancies among employees. This indicates that the traditional institutional factors that protect workers and also could decrease the flexibility of the labour market, such as labour market regulation, social protection and union activities, are not very well developed in Estonia and do not have a significant effect on the outcomes of the labour market. The labour market reform was launched in Estonia in 2009. The main idea of the New Employment contract was that the termination of employment relations became less expensive for employers. Although empirical evidence show that the Employment Contracts Act entered into force at a time when most lay-offs had already been effected.
\end{abstract}

JEL codes: J08, J21, J50, J63

Keywords: Labour policy, Estonian labour market, Labour market flexibility, Labour market and recession

\section{Introduction}

In Estonia, liberal market economy, relatively small public sector, and a relatively low tax burden result in scarce resources for policy options. Attempts to achieve annually balanced state budget has a pro-cyclical nature, which means that it works well during economic boom, exaggerating growth through growing public expenditures. The opposite took place during recession when government tried to cut expenditures in order to keep budget deficit under control. As taxes were relatively low, government also missed sufficient automatic stabilisers. In general we can say that government had limited fiscal tools to smooth cyclical fluctuations.

Additionally, the currency board system that was the basis for money supply until the introduction of euro (2011) set restrictions for money supply as well as for restraining inflation. There are many papers dealing with monetary policy limitation in

(c) 2013 Eamets; licensee Springer. This is an Open Access article distributed under the terms of the Creative Commons Attribution License (http://creativecommons.org/licenses/by/2.0), which permits unrestricted use, distribution, and reproduction in any medium, provided the original work is properly cited. 
currency board arrangement (see for instance Feuerstein and Grimm, 2006; Gilson, 2002; Moheeput, 2008 among the others).

It is commonly thought that an open economy can accommodate output shocks through either exchange rate or real sector adjustments. There are also theoretical models showing that in the case of pegged exchange rate, policy reform can be consistent if it renders either exchange rate or labour market flexibility (Castern, et al. 2004). The burden of adjustment to a loss in competitiveness in a currency board country must come from real economy. This adjustment would be facilitated by structural policies designed to increase labour market flexibility (Gilson, 2002).

Baltic labour markets are flexible and this has already been reported in the late 1990s (Berengaut, J. et al. 1998, for late period see Eamets, Paas, 2007) Just to illustrate the magnitude of labour market changes: as result of the economic boom between 2004 and 2007, employment reached 70\% and unemployment was 4\%; during recession unemployment grew over a period of one and a half year up to almost $20 \%$ and employment dropped to $53 \%$.

The objective of this paper is to show, using Estonia as an example, that if monetary policy and fiscal policy tools are insufficient and limited, economy will adjust via labour market channels. For quick adjustment labour market should be very flexible. We will observe how labour market and labour market institutions reacted during the recent Economic crisis. The situation in Estonia is rather unique, and very different from those in the old EU member states. Estonia implemented labour market reform in the middle of the deepest economic recession together with strong austerity measures and fiscal consolidation.

As widely reported in the economic press, the impression is that austerity policy worked well in Estonia, as it also worked in the other two Baltic economies: Latvia and Lithuania. In 2009, hit with the deepest GDP declines in the world, over the course of the crisis, all three Baltic states adopted austerity measures amounting to 8-9 percent of GDP, with an additional 3-4 percent in 2010 (Kattel, Raudla 2012). The same authors argue that the recent Baltic recovery has unique features that do not relate to domestic austerity policies, nor are they replicable elsewhere. According to Kattel and Raudla the Baltics "outsourced" their recovery. There are three phenomena behind the Baltic recovery, namely: the massive use of European Union (EU) fiscal funds, flexible labour market and integration of export sectors into the key European production networks.

Estonian labour market reactions to the crises were first reported by Masso and Krillo (2011). They showed in their comparative study how wages were reduced in all the Baltic countries, how wage inequality increased and they also touched on some other forms of labour market flexibility, like flows between labour market states and job flows. Among other things they concluded that if economic downfall is so deep then it seems to be the case that it is not possible to adjust labour market only through the employment cuts but also wage cuts are inevitable. They also concluded that labour markets in all three Baltic countries are very flexible.

This paper tries to summarise findings from literature and provide our own concept on how to measure labour market flexibility. Even if some measures on the macro level show rigidity of the labour market, on the micro level we can observe a lot of mobility, both on jobs' and employees' level. Also we will use more recent data, showing 
Estonian labour market situation after crisis in 2010. Some research about institutional changes in labour market and their labour market outcomes were launched in recent years, but these reports are only in Estonian. In this paper we will briefly introduce their results to the international audience.

The paper is organised as follows: in the first section, the changes in unemployment and the role of labour market institutions are discussed; thereafter, the main features of labour policy, labour market reform and trade union's situation are presented. The second part of the paper will focus on different aspects of the labour market flexibility and the final section summarises the main findings.

\section{Unemployment and labour market institutions}

There has been no explosion of unemployment in Estonia, rather, the unemployment has increased gradually since the 1990s along with the social disturbances, massive unemployment etc. In the March of 1999, the registered unemployment rate was $6,7 \%$, and ILO unemployment rate was $11.7 \%$.

The main reason for moderate unemployment growth was a sharp drop in labour force participation. Other factors included initial exchange rate undervaluation (which helped maintain average enterprise profit rates), flexible labour markets, low unemployment benefits, and net emigration to the Former Soviet Union (FSU).

As we can see from Figure 1, the changes in employment are mirror images of changes in unemployment. In only two years we can observe some asymmetry (2006 and 2004). These were the years when inflows to employment came mostly from inactivity.

The labour market in small open economies like Estonia largely depends on the neighbouring countries and the world market, and so the impact of the Russian crisis of 1998 on the Estonian labour market was considerable. As we can see from Figure 2 the official unemployment rate started to increase from the beginning of 1999 as many companies which had used internal reserves in 1998 had to change

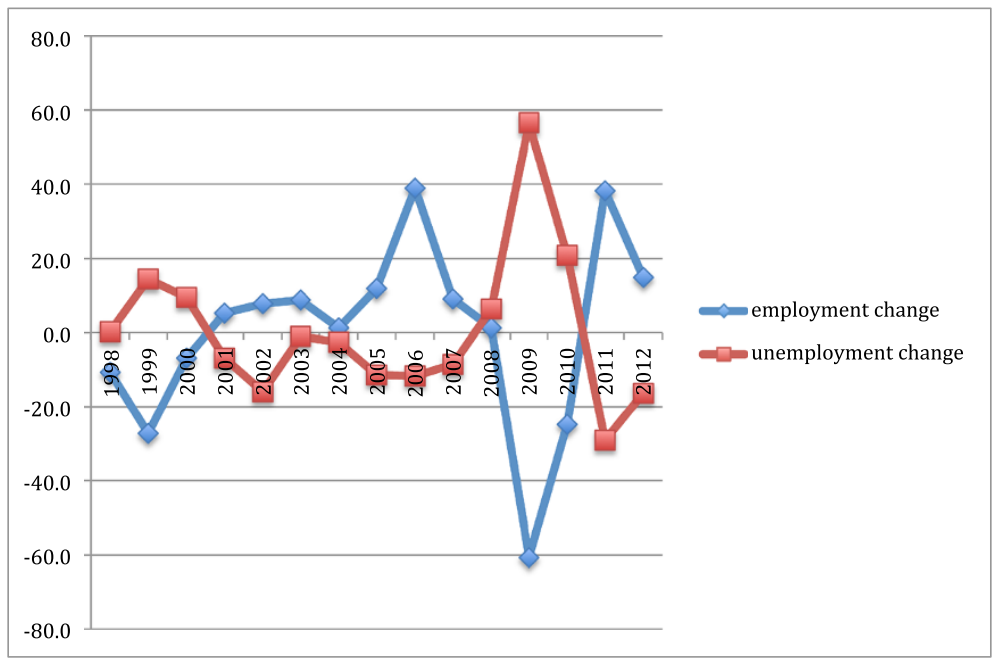

Figure 1 Employment and unemployment changes (thousands). Source: Estonian Statistics. 


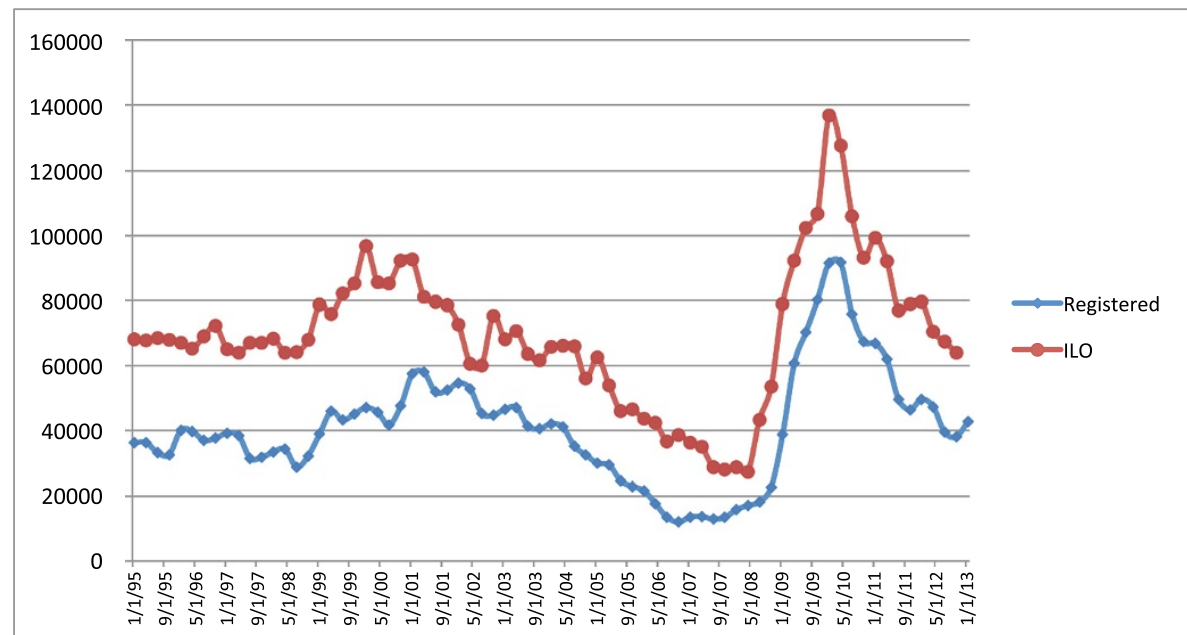

Figure 2 Registered and Labour Force Survey (ILO) unemployment (thousands). Source: National Labour Market Board and Estonian Statistics.

their personnel policy in 1999. This meant there was a time lag between the economic slowdown and unemployment, and a similar lag occurred in 2008. Although economic growth turned into a recession during the second quarter of 2008, the unemployment rate only started to increase sharply during the second half of 2008, resulting in a yearly rate of only $5.5 \%$.

In 2009, GDP decline in Estonia was almost 15\% and this was accompanied by an unemployment rate of $20 \%$ in the second quarter of 2010. Therefore, it could be easily predicted from experience of other small economies (like Finland) that after a deep recession, unemployment will remain sustainably high as many jobs are removed to countries with cheaper labour, firms change their profiles or firms simply become more efficient (Eamets, 2012). In spite of seasonality we can see from the dynamics of registered unemployment that there is a small increase in unemployment at the beginning of 2013. It is predictable from other countries' experience that due to structural unemployment the unemployment rate will not move back to the low level of pre-recession during the next 5-6 years.

In Estonia, the registered unemployment rate has always been lower than the unemployment rate based on the Labour Force Survey (LFS) (labelled as ILO unemployment). Between 1993 and 2006, for example, the difference between the two rates peaked at 6.7 percentage points in 2000. In general, in the early 2000 s the unemployment rates given by the LFS are nearly twice the registered unemployment rates. Today, registered unemployment is about $70 \%$ of total unemployment.

ILO unemployment rate is calculated based on the Estonian Labour Force Survey's database. The target population of the surveys were all working-age residents of Estonia. Working-age persons comprise, in our case, persons between the ages of 15 and 75. Sample size is about 4000 persons per quarter. 1995-1999 the survey was annual and conducted in the second quarter. From 2000 onwards, the surveys are conducted all year round and the results are provided for the quarters and for the year. 
Until the second quarter of 2000 the questionnaire of ELFS consisted of two parts:

- the part of the reference week in which the data were collected on the week preceding the survey;

- the retrospective part in which the data were collected on the changes of work in the years preceding the survey.

The quarterly results are received on the basis of continuous survey since the first quarter of 2000. Since the third quarter of 2000 the retrospective data are not collected.

Why are there so large differences between the two different unemployment rates? As stated by Arro et al. (2001), the difference results from several factors, among which the following are the most important:

- The inadequacy of the legislation and social guarantees for unemployment;

- The poor reputation of the Labour Market Board;

- The very limited willingness of employers to cooperate with the state job mediation system and,

- Various job seeking scenarios.

Indeed, a survey of 2008 on the public image of the Estonian Labour Market Board affirms that the institution is not popular among job-seekers, as a large number of them presume that the board cannot offer suitable jobs. Although the board started to provide additional services for other job-seekers and not only the unemployed, people continued to seek jobs through acquaintances, direct contact with employers or searches in electronic databases. Employers mostly preferred to seek employees through acquaintances and advertisements in newspapers (Tööturuameti maine... 2008).

The situation, nevertheless, changed with the recession in $2009^{1}$. While the economy was growing, most vacancies were actually filled directly by people changing jobs without an intervening period of registered unemployment (Labour Market... 2009). Non-Estonians, older people and the discouraged are usually in a worse position in the labour market, but due to the high demand for labour in 2006 and 2007 they participated in labour force to a larger extent than usual. The unemployment rate for non-Estonians, for instance, fell to $6.9 \%$ by 2007 from $15.2 \%$ in 2003 (Töövaldkonna areng 2008). In 2009, newly unemployed people who were eligible for unemployment insurance benefits or unemployment allowances started registering in unusually high numbers. As a result, the number of people registered as unemployed grew by $177 \%$ year-on-year in January 2009.

The process of registering as unemployed is quite complicated in terms of the legislation and social guarantees for unemployment ${ }^{2}$, and the level of unemployment allowances is very low.

\section{Labour policy}

Public sector expenditures in Estonia on labour market policy have also been very low. The labour market policy has mostly been passive, but as the unemployment allowance 
has been low compared to the average salary in Estonia (Table 1), the proportion of passive measures in all the labour market policy measures have remained low (Table 2). The LMP spending in 2005 in Denmark was almost 4.1 per cent of GDP and was the highest in the EU, whereas in Estonia it was less than 0.2 per cent of GDP (Expenditure on... 2008). When unemployment was high in 2009, the share of passive measures increased from $0.12 \%$ to $0.69 \%$ of GDP.

Additionally, the structure of active labour market policies in Estonia is less varied than that in other OECD countries, as most of the spending went on training costs and the administrative costs Labour Market Board and local officies, while other measures received little finance (Leetmaa et al., 2003). However, the reasons for the low spending on active labour market policies could include not only the different composition of the services offered to the unemployed, but also differences in the target groups entitled to the services ${ }^{3}$ and the short duration of the programmes in Estonia compared to those in other countries (Estonian Human... 2009).

Some changes took place in labour market policy during the crisis. There was a remarkable shift in National Labour Market Board ${ }^{4}$ policy in 2010. When before the crisis, the training was dominantly labour policy measure, then in 2010 it was replaced with employment subsidies. The amount of training allowances were reduced by $50 \%$ and the same amount was added to the employment subsidies. Rationality behind this shift was very clear: why just spend on training while vacancies almost disappeared and unemployment rate rose to $20 \%$. Instead, people should be kept at work, so that they could at least pay their everyday bills. Along the same lines was the social policy in the capital city, Tallinn. The organisation and financing of public jobs was the responsibility of local governments. Tallinn created a few thousand so-called social jobs during the crisis in order to provide at least a minimum income for low skilled labour.

An unemployment allowance was introduced in Estonia when the unemployment problem first emerged in 1991, and the system was then reformed in 2002. The law saw further considerable changes with the Labour Market Services and Benefits Act which came into force on 1 January 2006. The reform of 2002 introduced

Table 1 Unemployment allowance in Estonia, 1992-2008

\begin{tabular}{llll}
\hline Year & $\begin{array}{l}\text { Unemployment } \\
\text { allowance per month } \\
\text { (EEK) }\end{array}$ & $\begin{array}{l}\text { Unemployment } \\
\text { allowance } \\
\text { (EUR) }\end{array}$ & $\begin{array}{l}\text { Unemployment allowance } \\
\text { as percentage of minimum } \\
\text { wage (\%) }\end{array}$ \\
\hline 2000 & 400 & 25.6 & 28.6 \\
\hline 2001 & 400 & 25.6 & 25.0 \\
\hline 2002 & 400 & 25.6 & 21.6 \\
\hline 2003 & 400 & 25.6 & 18.5 \\
\hline 2004 & 400 & 25.6 & 16.1 \\
\hline 2005 & 400 & 25.6 & 14.9 \\
\hline 2006 & 400 & 25.6 & 13.3 \\
\hline 2007 & 1000 & 63.9 & 27.8 \\
\hline 2008 & 1000 & 63.9 & 23.0 \\
\hline 2009 & 1000 & 63.9 & 23.0 \\
\hline 2010 & 1000 & 63.9 & 23.0 \\
\hline
\end{tabular}

Source: Ministry of Social Affairs. 
Table 2 Spending on labour market policy as \% of GDP

\begin{tabular}{llllllll}
\hline & $\mathbf{1 9 9 4}$ & $\mathbf{1 9 9 8}$ & $\mathbf{2 0 0 2}$ & $\mathbf{2 0 0 7}$ & $\mathbf{2 0 0 8}$ & $\mathbf{2 0 0 9}$ & $\mathbf{2 0 1 0}$ \\
\hline Total expenditures & 0.24 & 0.16 & 0.15 & 0.15 & 0.23 & 0.93 & 0.86 \\
\hline - passive & 0.11 & 0.08 & 0.09 & 0.06 & 0.12 & 0.69 & 0.63 \\
\hline - active & 0.13 & 0.08 & 0.06 & 0.09 & 0.1 & 0.23 & 0.23 \\
\hline
\end{tabular}

Source: before 2007 Leetmaa et al. 2003, since 2007 Unemployment Insurance Foundation data.

unemployment insurance, and the most important change in 2006 was that a casemanagement approach was adopted for services at the Labour Market Board.

An unemployment insurance was created in 2002 in Estonia as a type of compulsory insurance based on the principle of solidarity; the first benefits were paid out at the beginning of 2003. The benefits provided are: unemployment insurance benefit, benefit for collective termination of employment contracts, and benefit for employer's insolvency. For the employee, as the insured party, the unemployment insurance contribution rate is between 0.5 and 2.0 percent and for the employer it is 0.25 to 1 percent of the wages paid to the employee. From 2006 to 2008, the unemployment insurance contribution rate was 0.6 percent for employees and 0.3 percent for employers. On 1 August 2009, unemployment insurance premiums in Estonia increased to $2.8 \%$ of wages for employees and to $1.4 \%$ of the payroll for employers. The increase was explained as being necessary for the Unemployment Insurance Fund to cover the growing costs caused by the continuing recession and by new redundancy regulations that had raised unemployment levels and the number of benefit recipients. From January 2013 the contributions were lowered again: the employer pays $2 \%$ and the employee $1 \%$.

Insured people who are registered as unemployed and who have been insured for at least 12 months during the 36 months (until 2006, during 24 months) prior to registering as unemployed, have the right to receive unemployment insurance benefits. The amount of benefit paid depends on the recipient's previous salary and it decreases the longer the unemployment spell lasts (Health, Labour... 2008).

In Estonia, the requirement for a record of minimum contributions for unemployment allowance has been strictly enforced and unemployed people who fail to fulfil this criterion may not apply for the unemployment allowance. Eligibility for assistance requires a record of previous employment and proof that the applicant is actively seeking for a job. This includes registration as unemployed at the local labour office and visits to the labour office at least every 30 days. The payment of benefits may be terminated if a person refuses a suitable job offer. Strict criteria for receiving unemployment benefits cause difficulties for recent graduates without working experience and for people who should only work for a few more years before retirement (Eamets 2000).

In 2006, the number of different types of labour market service was increased under the new act, with four services for the disabled (Health, Labour 2008). Each unemployed person is additionally handled by a caseworker, who helps to resolve the client's unemployment problem and assist them in finding a job as soon as possible (Estonian Human 2009). Overall the role of active and passive labour market policies in Estonia has been modest and there are very few surveys investigating the crisis time. 
The analyses of Lauringson (2011) showed that unemployment benefits increase unemployment duration even during a very severe economic slowdown. However, this effect is slightly milder than in somewhat better economic circumstances.

In addition, her studies of post-unemployment job quality confirmed that this longer unemployment and job search duration might also incur higher post-unemployment job quality. This suggests that more generous benefits prolong the job search period and unemployment spell, but the accepted jobs will match the workers' skills and needs better, which is shown above all by job duration as a proxy for match quality.

The other results of Lauringson (2012) indicate that on the one hand, it might be quite difficult to become eligible for unemployment benefits particularly for the unemployment insurance benefit that has a higher level. This is reflected in the data for spending on unemployment benefits per unemployed person when Estonia is compared with other EU countries. On the other hand, once a person becomes eligible for unemployment benefits, it seems quite easy to stay on the benefit.

\section{Labour market reform in 2009}

In order to increase the administrative capacity of the labour market institutions, the Labour Market Board and the Unemployment Insurance Fund were merged in 2009. The aim of this institutional change was better integration of labour market services and benefits. In addition, better control was established, making it possible to increase the administrative capacity.

The services provided by the Unemployment Fund are:

1. Information supply about the labour market situation and about labour market services and benefits.

2. Job mediation. This service is free of charge to job-seekers, the unemployed and employers alike.

3. Labour market training. The training can last for up to one year. Those taking part in a training lasting for more than 40 hours, receive a grant as well as transport and accommodation allowances.

4. Career counselling. This is designed to help people make and carry out informed decisions about their career development.

5. Work experience. This is a labour market service that lets people gain practical experience in the work place. The maximum length of a work experience placement is four months.

6. Public work. Public work is organised by local government departments, non-profit organisations and foundations who pay the participant at least the hourly rate of the minimum wage for their work.

7. On-the-job experience. On-the-job experience normally involves simple tasks that do not require special knowledge or for which the necessary skills can be learnt while working under the guidance of a supervisor. The service is provided for a maximum of three months at any one time.

8. Wage subsidy. This is a benefit paid to employers who hire an unemployed person. It is designed for high-risk groups such as people released from prison, the long-term unemployed and young unemployed people. 
9. Business start-up subsidies. These can be applied for by unemployed people who are at least 18 years of age and have completed business training or have higher or vocational education qualifications in economics or business experience. The one time amount they receive is 4474 EUR.

10. Adaptation of work premises and equipment. This is a service designed for unemployed people with disabilities.

11. The special measures for disabled persons.

The new Employment Contract Act (ECA) entered into force in July 2009 and brought the labour law into line with the principles of the private law. The previous ECA dated back to 1992 and needed considerable amendment and modification because it did not meet the needs of the labour market. The earlier Employment Contracts Act, Wages Act, Holidays Act, and Working and Rest Time Act were all integrated into one Employment Contracts Act, which reduced the administrative burden and abolished several formal provisions in labour law, like Labour Record Book etc.

An important change was that the compensation paid by the employer, if an employment contract was cancelled due to redundancy, was cut to one month's wage. If the employment relationship had lasted 5-10 years, the Unemployment Insurance Fund would pay compensation of one month's wage and if the employment relationship had lasted for over 10 years, it would pay compensation of two months' wages. In addition, advance notice of redundancy was shortened from 2-4 months to 15-90 days. The new act also allowed the employer to reduce the employee's wages temporarily. An employer who cannot provide the employee with the agreed amount of work due to unforeseen economic circumstances beyond the employer's control may reduce the employee's wages for up to three months over a twelve-month period to a reasonable extent, if the contractually agreed wage would be unreasonably burdensome for the employer. The lowered wage cannot be lower than the official minimum wage set by the government.

In order to avoid relatively sharp decline in employment protection, the income protection for the unemployed was to be enhanced through raising the unemployment benefit replacement rate and easing the eligibility for unemployment insurance. The unemployment income replacement rate was to be raised from 50\% to 70\% during the first 100 days of unemployment, and from $40 \%$ to $50 \%$ afterwards. Those leaving their jobs voluntarily were also to receive unemployment insurance benefits. However, adoption and implementation of these measures have been postponed to 2013 (Brixiova, Egert; 2012). The major argument was the economic crisis that hit Estonia in 2009. In May 2012 Parliament adopted new amendments to Labour Contract Law, which basically abolished all abovementioned agreements to increase social protection of unemployed persons. Moreover, this agreement was achieved on a national level in tripartite negotiations between social partners and Government in 2008. Now, however, Government unilaterally refuses to fulfill the agreement. The major argument was changing economic environment and shortage of sufficient resources. Social security issues were part of the deal as to why unions agreed to the flexibilisation of labour market in the first place. As left wing parties and unions have a small role to play in Estonian political landscape, there was no public unrest with such behavior of Government. 
In spite of concerns, the new ECA did not lead to any major changes in trends in the labour market. Major dismissals had already been made before 1 July 2009, and this alone actually proves that the Estonian labour market was sufficiently flexible under the old Employment Contract Act (Praxis, 2013).

Some researches have tried to find a link between the persistence of unemployment and the institutional settings. Particularly in new member states, but they found rather weak relations. Cuestas et al. (2011) found, firstly, that it is difficult to draw any clear link between labour market institutions and unemployment persistence in the individual CEE countries. This result is in line with the conclusions in, inter alia, Cazes and Nesporova (2004). Second, there appears to be a close correlation between the level of economic development and the degree of unemployment persistence. The countries that most closely resembled the old EU countries in terms of income level and government characteristics, also appear to resemble these countries in terms of unemployment persistence. (Cuestas, et al., 2011).

The research done by Malk (2012) showed that since the Employment Contracts Act came into force, the flows between labour market states have been increasing and the law has had a positive impact on the market mobility. However, looking at the flows between specific labour market states revealed that the Act has had a statistically significant impact on the probability of moving out from employment but not on the probability of moving into employment. The analysis also showed that the Act has had a statistically significant impact on the probability of moving from unemployment to inactivity. In addition, it appeared that the Act has had a negative impact on the probability of job-to-job mobility.

\section{Trade unions}

Since the beginning of the 1990s trade unionism in Estonia has undergone a lot of changes as the old models of operation had to be replaced by new ones. The changes in principles were accompanied by a sharp fall in density rates, especially during the first years of independence. In Soviet times unions were a part of the regime and so membership was compulsory for all workers. Today, the density rate is around 7-8\%.

There are two major trade union confederations in Estonia: The Estonian Trade Union Confederation (EAKL) and Estonian Employees Unions Confederation (TALO).

EAKL comprises of 20 branch unions that represent state and municipal government officials, education workers, health care workers, transport workers (including road, railway, sea and air transport), industrial workers (including energy, light industry, food industry, timber and metal industry) and people employed in the service sector (postal, communication, trade, hotel and cleaning sector workers, etc.). TALO covers mostly public sector employees.

Union membership saw a severe decline during the transition period, yet recent years show some stabilisation (see Table 3). The sharp drop in 2010 happened because the teachers' union left TALO in 2010. The teachers' union is large and influential and it decided to remain independent of central confederations.

Some part of the fall in membership was also caused by the general shrinking of the labour force and the increase in unemployment. In addition, in recent years some unions have started to exclude symbolic members who do not pay the proper 
Table 3 Trade union membership and participation rate

\begin{tabular}{lrrrrrrrr}
\hline & $\mathbf{1 9 9 1}$ & $\mathbf{1 9 9 5}$ & $\mathbf{2 0 0 1}$ & $\mathbf{2 0 0 6}$ & $\mathbf{2 0 0 7}$ & $\mathbf{2 0 0 8}$ & $\mathbf{2 0 0 9}$ & $\mathbf{2 0 1 0}$ \\
\hline Labour force (aged 15-69, thousands) & 818.7 & 701.4 & 655.2 & 681.3 & 682 & 689.1 & 684 & 678.8 \\
\hline EAKL members (thousands) & 699.6 & 139.2 & 50 & 43.8 & 39.1 & 38 & 35.8 & 33 \\
\hline TALO members (thousands) & - & 47 & 37 & 20 & 17.7 & 17 & 15 & 4.9 \\
\hline Total no. of union members (thousands)* & 699.6 & 186.2 & 87 & 63.8 & 56.8 & 55 & 50.8 & 37.9 \\
\hline Union membership as \% of labour force & 85.5 & 26.5 & 13.3 & 9.4 & 8.3 & 8.0 & 7.4 & 5.6
\end{tabular}
(aged 15-69)

Sources: EAKL, TALO, Estonian Statistics.

Notes: The membership numbers give the situation at the end of December of each year; labour force numbers are average numbers for the year.

* The actual number of trade union members is in fact somewhat higher than what is presented in the table, as the number in the table is the number of members of the central confederations (EAKL and TALO). There are trade unions that do not belong to those two organisations.

membership fees for their membership reports. There are several reasons behind the low rates of participation in the trade union movement:

- Industrial relations are often employer-dominated and stricter legislation on the participation of employees is required for any improvement in the situation of industrial democracy;

- The low level of activity of labour organisations is also a result of the relatively bad financial circumstances of the trade unions; the qualification of trade union staff also needs to be improved.;

- Society is not informed enough about trade union activities and their overall negotiating power is not very high;

- The decline in membership has been affected by general economic changes similar to those in the old EU members, such as structural changes in the economy, the growth of the service sector, growth of SMEs and self-employment, and increases in atypical labour.

Trade unions in Estonia are organised by sectors, meaning they cover all the employees working in a given sector. The majority of trade unions represent an entire sector although there are exceptions such as occupational trade unions that unite employees in one occupation only. Some industries such as construction and banking are union-free in Estonia.

There are also some trade unions in Estonia that do not belong to any association or central body and that act autonomously. In most cases their role outside their own organisation is practically invisible and their political influence is non-existent. Exceptions are perhaps the Estonian Education Personnel Union (EEPU) with 10,500 members and the Estonian Medical Association (Arstide Liit), with 2800 members. The professional association of doctors is relatively powerful and has successfully lobbied the government on various issues concerning working conditions, such as wages and working time. Doctors and other medium level employees in health care drew public attention to themselves with a major strike in 2012.

In Estonia, we do not see the pluralistic unionism in the sense that several trade unions could exist, each of them unifying employees with a distinct ideological and political vision. Both EAKL and TALO have internal pluralism, which means that they bring together employees with different political views and ideologies, and at the same 
time these different convictions are reflected in their strategies and opinions. Both confederations and their members base their strategies and approaches on the interests of the employee and not on political or other ideologies. The difference between the two big national trade union associations lies mainly in the kind of employees they represent, blue-collar or white-collar (Chassard, 2001). The EAKL especially is a devoted advocate of tripartite principles, while TALO's attitude is more reserved and it withholds its opinion about various issues because of its narrow niche, focusing on agreements with the government for its members in the public sector ${ }^{5}$.

\section{Labour market flexibility}

The flexibility of the labour market is a topic that has been much discussed in the Estonian media and which different authors treat very differently. According to some top politicians, labour market rigidity is the most serious problem facing the Estonian economy. Estonian prime minister has pointed out several times the ranking of Estonia as 163rd out of 181 countries in the World Bank's Ease of Doing Business Index 6 . At the same time, it should be remembered that one single indicator alone gives a picture that is very one-sided and does not consider all the aspects of labour market flexibility.

In our interpretation labour market flexibility can be assessed at micro and macro levels (Eamets and Paas, 2007). At the macro level, the flexibility of the labour market is measured by legislation and regulations and the flexibility of wages; the latter also reflects the influence of trade unions. The international indexes noted earlier reflect this aspect of labour market flexibility. At the micro level, or at the worker and company level, flexibility is indicated by how often workers move between different labour market states, for instance, how easy it is to move from unemployment to employment. In addition, the flows of workers also show functional flexibility or occupational mobility, or how often people change their occupation, or how simple it is for companies to replace workers with each other. The third aspect of worker mobility is geographic mobility. Job flows show how many companies create new jobs or close old jobs during a given time period, usually one year. The last element at the company level is the flexibility of working hours or to what extent flexible work schedules, part-time work, overtime, and similar policies are implemented (see Figure 3).

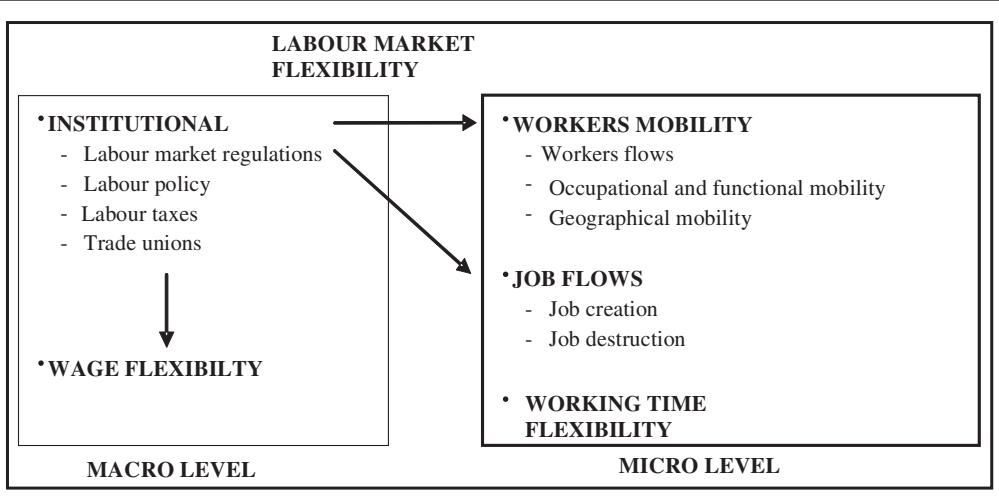

Figure 3 Labour market flexibility at the micro and macro levels. 
Boeri and Garibaldi (2007) found a high degree of macroeconomic wage flexibility in new member states and they suggested that jobless growth in these countries was related to productivity enhancing job destruction in the aftermath of prolonged labour hoarding. Their empirical analyses suggested that tight fiscal policies, rather than being harmful to job creation, may actually improve the employment performance of the region.

Lehmann and Muravjov (2012) used a unique dataset covering the countries of Eastern Europe and Central Asia over the period 1995 to 2008, and found a robust negative impact from stricter employment protection on employment and a significant positive impact on youth unemployment, and that active labour market policies do not affect employment but have a major effect on all three types of unemployment, in particular youth unemployment.

There is a paradoxical situation in Estonia, where macro indicators like the OECD Employment Protection Legislation Index show that the Estonian labour market is rigid and over-regulated, but data from company level shows that the labour market is in fact flexible (see Eamets, Masso 2005). Similarly, according to the World Bank's Ease of Doing Business Index and the Heritage Foundation's Index of Economic Freedom, the Estonian labour market is rigid and over-regulated. However, the fact is often overlooked that the rigidity indicators operating at the state level are established by regulations or laws, and in many other European countries, minimal requirements are established in law and the majority of regulations are left for the social partners to agree upon. In other words, many international indices do not reflect the actual regulation of the labour market in countries where the influence of trade unions is the strongest. In order to see the actual flexibility of the labour market, it is necessary to analyse the micro data as well. Below, we will try to fill this gap in the description of Estonia's labour market.

Some aspects of labour market flexibility, flows of workers between different labour market states, and the number of jobs that are created and lost in companies will be examined more closely as follows. In addition, we present some facts about wage flexibility and working time flexibility.

\section{1. Worker flows}

The first point to consider is how people move between different labour market states. People can be in one of three different states in the context of the labour market - employed, unemployed or inactive. The employed are those who have jobs; the unemployed are looking for jobs; and the inactive are not looking for jobs and are not employed ${ }^{7}$. Since people are constantly moving from unemployment to employment, becoming unemployed or leaving the labour market, or becoming inactive, there are constant flows in the labour market, and this is called the labour market mobility ${ }^{8}$. Great changes in the economy, such as major reforms or crises, cause an increase in labour market mobility, while there is less movement between various labour market states during stable periods. Flows are indicated by the combination of letters so that $\mathrm{EU}^{9}$ means movement from employment to unemployment, and IE from inactivity to employment. In total, there are nine possible flows. 
Here we use Labour Force Survey data. The minimum length of the fixed periods was one month for all three surveys. If, for instance, there was a period of less than a month between leaving one job and starting a new one, this period was not reflected in the questionnaire as a separate period of unemployment. For each period, its starting and ending time (month) and the features characterising the period were fixed.

Each person's situation in the labour market is assessed over one year, for instance from January to January. This means that if one person was unemployed in January 2000 and employed in January $2001,{ }^{10}$ we get one movement from unemployment to employment. In reality, as we move diagonally along the matrix we see flows within the same state, or stable states. There is, however, one exception, because we can speak of movement within employment as EE flow, or job-to-job flow, in a certain sense, because a person may change jobs during the year without leaving employment.

In analysing the empirical data, it is important to know the percentage of all employed people or all unemployed people who changed their status. This shows the ratio of flow compared to the number of people that are in the given labour market state. The dynamics of the flows is presented in the following Figure 4.

We can see that during the crises outflows from employment increased very rapidly and the same is true for IU flows. Somewhat surprising is that flows from inactivity to employment were relatively stable even during very fast increase in unemployment. Job-to-job flows declined rather drastically during the crisis.

\subsection{Job flows}

Job flows are not defined as the physical movement of jobs, for instance from Estonia to countries with cheaper labour such as China, but the creation or destruction of jobs within companies. Data from the Business Register are used to calculate flows and a job is considered to have been eliminated when it exists in January of one year, but not in January of the following year. The creation of jobs is the opposite. Five indicators are used to measure the flows: the job creation rate, the job destruction rate, the net

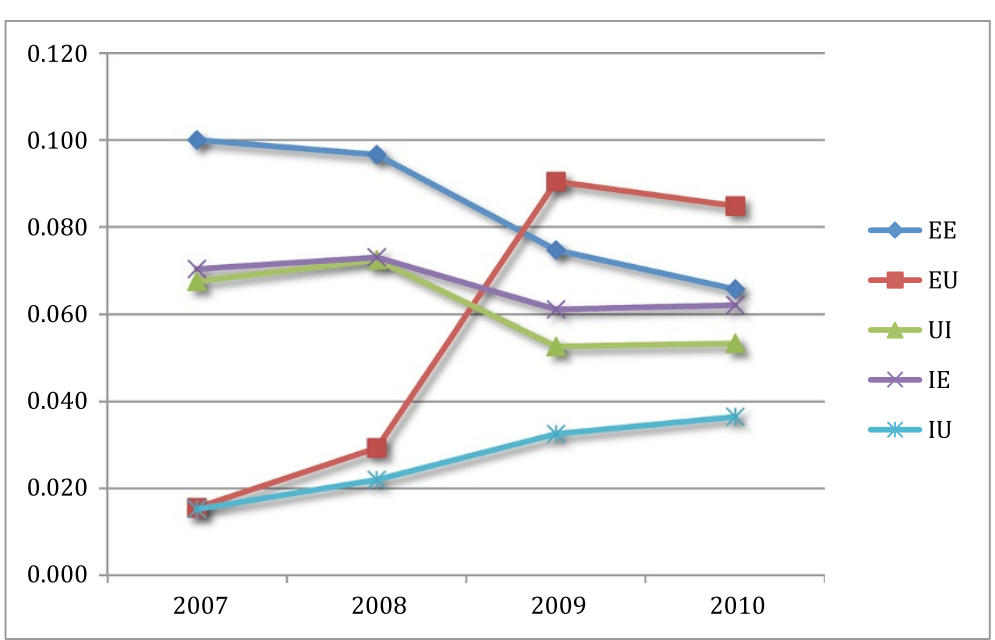

Figure 4 Labour market flows in Estonia during economic boom and depreciation. Source: Labour Force Survey data. 
change, the gross rate or change between the two, and the excess job reallocation rate or the gross effect subtracted from the absolute value of the net effect. The higher the net effect, the more volatile or flexible the labour market, the more jobs are eliminated and the more new jobs are created.

This strand of empirical research has gained importance since the research by Davis and Haltiwanger (1992) was published, and it has produced a lot of evidence from the Western countries. The main findings, as summarised by Haltiwanger, Lehmann, and Terrell (2003), are that:

(1) In early transition, job destruction dominates job creation, whereas at later stages job destruction and creation are roughly equal;

(2) There is a large increase in worker flows ${ }^{11}$ when the transition begins;

(3) New and small private firms contribute disproportionately to job creation, while most of the job destruction occurs in state-owned firms;

(4) There is a great deal of heterogeneity in job creation and destruction within narrowly defined industries, but inter-industry reallocation is still more important than in western economies.

In the case of Estonia, we used the database of the Estonian Commercial Register (for more detailed description of data see e.g. Masso et al., 2007). Dataset comprises almost all registered firms from the second half of 1990s and include the population of firms from all the economic sectors, regions, ages and size classes. Problem with registry data is that as far as the central variable in our analysis - the number of employees - is concerned, we can observe only increases or decreases in firms' total number of employees, but we have no information about how many people were hired or fired during a year.

Examining the dynamics of the excess reallocation rate in Estonia (Table 4), we see that this rate was fairly stable in 2005-2008, but it dropped rapidly during the recession.

Regional differences can be seen during the crisis. As the unemployment rate in some areas may be double that in others, we can also see that the excess rate is high in the capital area at $17.6 \%$ and low at $8.7 \%$ in the North-East of Estonia, where the Russian-speaking minority population and heavy industries dominate.

There is much more volatility in the private sector than in the state sector and more in smaller firms than in big firm.

When we put the Estonian indicators into an international context (see Masso, Eamets Philips 2007), then it appears that Estonian labour market volatility is lower than it is in the Nordic countries, but it is at the same level as in the USA. It was also showed that job flows in Lithuania and Poland were slightly higher than those in Estonia. Job creation and destruction levels in the old EU member states are a small fraction of those in Estonia. Therefore, the flows of people between various labour market states and the statistics for the destruction and creation of jobs do not confirm that Estonia has a very rigid labour market. There is clearly some statistical information noise in this data, because the re-labelling of jobs and redistribution of functions within companies are reflected ostensibly as job destruction or creation. However, a similar bias exists in all databases that reflect register data. 
Table 4 Job creation and job destruction rates in Estonia during the crisis

\begin{tabular}{|c|c|c|c|c|c|c|c|c|c|c|}
\hline & \multicolumn{2}{|c|}{ Job creation } & \multicolumn{2}{|c|}{ Job destruction } & \multicolumn{2}{|c|}{ Net change } & \multicolumn{2}{|c|}{ Gross change } & \multicolumn{2}{|c|}{ Excess reallocation rate } \\
\hline & $2005-7$ & 2009 & $2005-7$ & 2009 & $2005-7$ & 2009 & $2005-7$ & 2009 & $2005-7$ & 2009 \\
\hline Northern Estonia & $16.9 \%$ & $8.8 \%$ & $9.3 \%$ & $19.4 \%$ & $7.6 \%$ & $-10.6 \%$ & $26.2 \%$ & $28.2 \%$ & $18.6 \%$ & $17.6 \%$ \\
\hline Central Estonia & $11.4 \%$ & $4.9 \%$ & $8.9 \%$ & $17.3 \%$ & $2.5 \%$ & $-12.4 \%$ & $20.3 \%$ & $22.2 \%$ & $17.8 \%$ & $9.8 \%$ \\
\hline North-Eastern Estonia & $8.6 \%$ & $4.3 \%$ & $8.3 \%$ & $24.7 \%$ & $0.4 \%$ & $-20.3 \%$ & $16.9 \%$ & $29.0 \%$ & $16.5 \%$ & $8.7 \%$ \\
\hline Western Estonia & $14.3 \%$ & $6.3 \%$ & $10.0 \%$ & $21.9 \%$ & $4.4 \%$ & $-15.6 \%$ & $24.3 \%$ & $28.2 \%$ & $19.9 \%$ & $12.6 \%$ \\
\hline Southern Estonia & $14.6 \%$ & $7.0 \%$ & $9.3 \%$ & $20.1 \%$ & $5.3 \%$ & $-13.1 \%$ & $23.9 \%$ & $27.1 \%$ & $18.6 \%$ & $14.0 \%$ \\
\hline \multicolumn{11}{|l|}{ Ownership } \\
\hline State & $3.0 \%$ & $0.7 \%$ & $4.7 \%$ & $7.4 \%$ & $-1.7 \%$ & $-6.7 \%$ & $7.7 \%$ & $8.1 \%$ & $6.0 \%$ & $1.4 \%$ \\
\hline Domestic private & $15.1 \%$ & $7.1 \%$ & $9.9 \%$ & $20.7 \%$ & $5.2 \%$ & $-13.6 \%$ & $25.0 \%$ & $27.8 \%$ & $19.8 \%$ & $14.2 \%$ \\
\hline Foreign & $16.1 \%$ & $7.0 \%$ & $7.4 \%$ & $18.8 \%$ & $8.8 \%$ & $-11.8 \%$ & $23.5 \%$ & $25.8 \%$ & $14.7 \%$ & $14.0 \%$ \\
\hline \multicolumn{11}{|l|}{ Firm size } \\
\hline $1-9$ & $16.2 \%$ & $7.0 \%$ & $10.5 \%$ & $20.2 \%$ & $5.7 \%$ & $-13.2 \%$ & $26.7 \%$ & $27.2 \%$ & $21.0 \%$ & $14.0 \%$ \\
\hline $10-19$ & $14.5 \%$ & $5.7 \%$ & $8.1 \%$ & $20.2 \%$ & $6.5 \%$ & $-14.5 \%$ & $22.6 \%$ & $25.9 \%$ & $16.1 \%$ & $11.4 \%$ \\
\hline $20-49$ & $12.9 \%$ & $4.5 \%$ & $7.3 \%$ & $18.3 \%$ & $5.5 \%$ & $-13.8 \%$ & $20.2 \%$ & $22.8 \%$ & $14.7 \%$ & $9.0 \%$ \\
\hline $50-99$ & $11.1 \%$ & $4.6 \%$ & $5.1 \%$ & $14.6 \%$ & $6.0 \%$ & $-9.9 \%$ & $16.2 \%$ & $19.2 \%$ & $10.2 \%$ & $9.3 \%$ \\
\hline $100-249$ & $11.2 \%$ & $6.9 \%$ & $8.0 \%$ & $18.0 \%$ & $3.2 \%$ & $-11.1 \%$ & $19.2 \%$ & $24.9 \%$ & $16.0 \%$ & $13.8 \%$ \\
\hline More than 250 & $8.7 \%$ & $6.6 \%$ & $4.6 \%$ & $9.4 \%$ & $4.1 \%$ & $-2.8 \%$ & $13.3 \%$ & $16.0 \%$ & $9.2 \%$ & $13.2 \%$ \\
\hline Total economy & $14.8 \%$ & $6.9 \%$ & $9.2 \%$ & $19.8 \%$ & $5.5 \%$ & $-12.9 \%$ & $24.0 \%$ & $26.7 \%$ & $18.5 \%$ & $13.8 \%$ \\
\hline
\end{tabular}

Source: Masso and Krillo (2011), author's calculation. 
In addition, Eamets and Masso, 2005, have proposed violations of the labour laws as the reason for job mobility. Although it is relatively complicated to dismiss workers under the law, a large number of workers leave their jobs by "mutual agreement"12, which usually means that the workers often do not receive the benefits to which they are entitled to unless a separate agreement has been reached.

In summary, it can be said that an analysis of the micro indicators confirms our assertion that Estonia's labour market is flexible and operates as a kind of buffer for balancing the economy. This is proven by the relatively large flows between labour market states and the high rate of job creation and destruction. The final indicator is the rapidly increasing unemployment rate in the recession starting from the third quarter of 2008.

\subsection{Wage flexibility}

Estonia is characterised by a high degree of wage flexibility and almost fully decentralised wage setting. Wages are determined mostly on the company level. Exceptions are minimum wages, wages for civil servants and some industries with strong unions (transportation sector) that are set on the national level. Wage flexibility declined during the boom time, when before 2004 wage increase followed closely productivity increase (Babetcky, 2008, Room and Uusküla, 2009), then from 2005 to 2007 the increase in real wages was largely in excess of labour productivity growth due to labour shortage resulting from rising demand and increasing labour emigration mostly to Finland. The key factor behind the wage flexibility is performance related bonus system. As a result, employees' salaries consist of relatively low basic wages and relatively high additional fees and bonuses. According to Rõõm and Dabušinskas (2011) approximately $80 \%$ of Estonian firms pay some kind of performance-related bonuses. The share of bonuses are around $20 \%$ of the total payment. Another interesting fact about pay systems is that $26 \%$ of Estonian companies remunerate employees on piece-rate bases, about 30\% pay hourly based wages. In the euro area these two components of pay methods consist in average not more that $20 \%$ of total remuneration methods. Monthly based wage is largely dominating (Rõõm and Dabušinskas, 2011).

When the economy is booming, performance pay increases rapidly, but during recession, this may result in a rapid decline of gross wages in certain sectors (Eamets, Leetmaa 2008). This phenomenon caused massive nominal wage cuts during recession in several sectors. If we take II quarter of 2008 as a pike of average wages, we can see from Figure 5 that only by the end of 2011 most of the sectors, except public administration, caught up to the level of 2008. In public administration and construction wages dropped by 20 per cent points.

High seasonality of wages can also be pointed out. During the summer months, there is a relatively large increase due to holiday payments and at the end of the year, there are also different annual bonuses being paid to the employees. There are also anecdotal evidence that in some sectors (for instance in construction) hourly wages for some occupations or work tasks remained the same but the piece-wise job requirements were raised. It means that you have to work more in order to get the previous payment. 


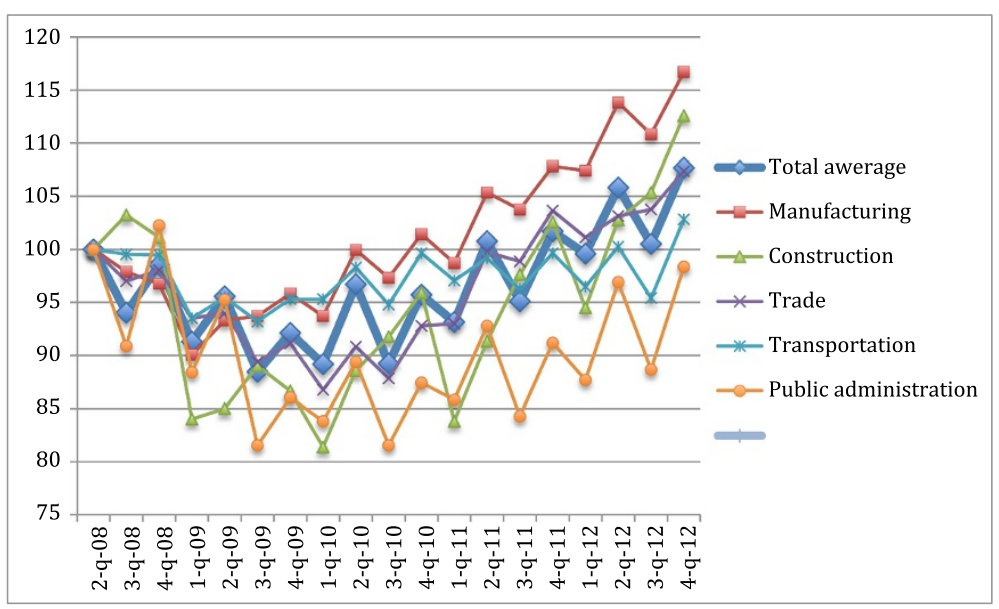

Figure 5 Average nominal monthly pre-tax wages ( 2 quarter $2008=100$ ). Source: Estonian statistics.

\subsection{Working time flexibility}

One potential way to adjust the labour market to the changing market conditions is to reduce the working hours. Svejnar and Semerak (2009) argue that the observed adjustment in the form of a shorter working week in the new member states may be temporary and could later translate into unemployment.

In Estonia's case this was probably true as unemployment did not peak until 2010. Shortened working hours may appear due to the higher frequency of parttime employment, extra vacations etc. According to the Estonian LFS, among the various reasons for working less than the usual number of hours during the previous week, the importance of the reason "Shortage of work or hours" increased from six percent in 2008 to 14 percent in 2009 (Masso and Krillo 2011).

In total, working time declined by 3.8 percent in Estonia in 2009. The biggest decline took place in the construction and in the hotel sector. If we look at Figure 6, we can see that in Estonia the fluctuation of changes differs drastically from that of the comparison group. In comparison group we have Eurozone countries and Germany from old Europe and Latvia and Lithuania as countries with relatively flexible labour markets, plus EU 27.

Particularly tremendous differences occur if we look at the changes in construction: Latvia had a similar drop in the working hours $(-6 \%)$, and it has been declining since 2009. In the case of Estonia, we see a sharp decrease and then a fast recovery, while in the hotel sector the working hours decline with progressive speed. Relatively big fluctuation is also observable in public administration sector. For raw data, see the Table 5 in Appendix 2.

Another form of working time flexibility is part-time work. As economic activity declined during the crisis, the working time of employed persons was reduced and full-time workers were given part-time work.

The Estonian Labour Force survey enables us to distinguish between "ordinary" part-time work and so called "forced" part-time work. Respondents in Labour Force Survey can reply that they are working part-time for economic reasons (e.g. their firm was not able to provide a full-time job because of a decline in demand or for other crisis-related reasons). In such cases a worker is underemployed, in 


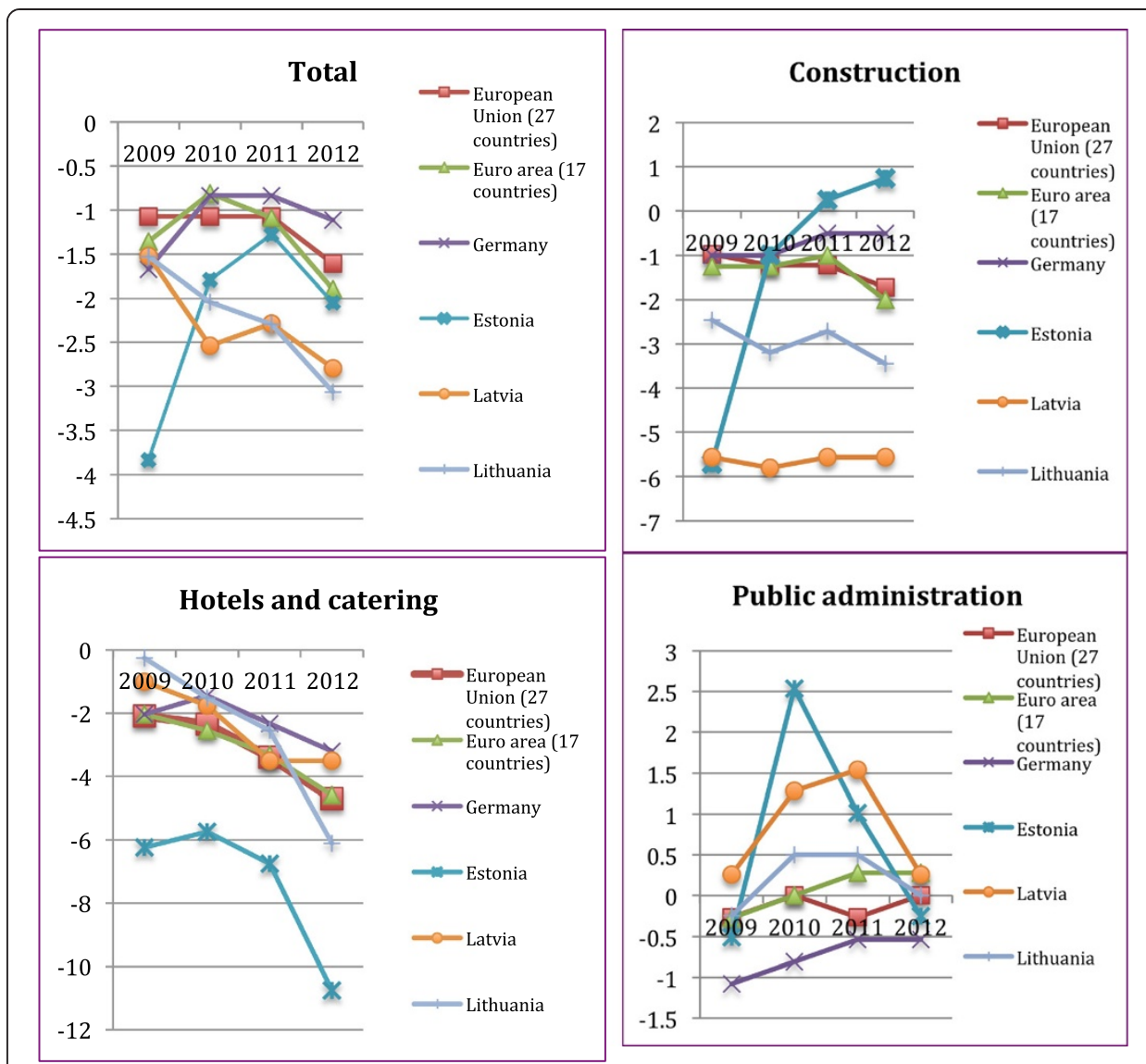

Figure 6 Annual changes in actually worked hours. Source: Eurostat, author's calculations.

other words s/he would like to work more, but there are no job opportunities in his/her firm. We can see from Figure 6 that the share of part-time work is very low in Estonia compared with the other EU countries. In average only 4.8 of males and $14.8 \%$ females work part-time. During the crisis part time work increased proportionally for both gender groups. Interesting is that when recovery started, then males part-time work reduced rapidly, while female part-time continued to increase. As we can see from Figure 7 the main reason was most likely the increasing underemployment among females.

\section{Conclusion}

In the early 1990s, Estonia introduced a rather unique economic policy. It is characterised by limited monetary policy, low taxes, open foreign trade policy, low public sector debts etc. Nevertheless, these policy options also had some negative effects. The annually balanced state budget has a pro-cyclical nature, which means it works well when the economy is growing by exaggerating growth through increased public spending but the opposite effect occurs in a recession when the government tries to cut spending in order to keep the budget deficit under control. As the personal income tax rate is flat and relatively low at $21 \%$ and social security contributions are not directly linked to inflation, the government is also lacking in 


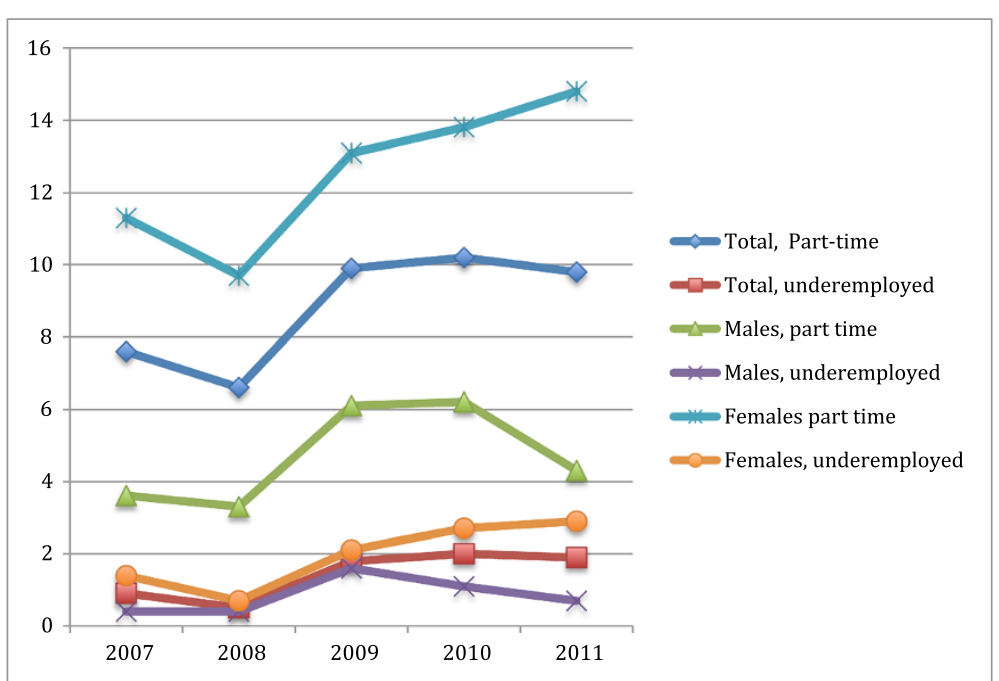

Figure 7 Part time-work and underemployment of females and males (proportion of all employees, \%), 2007-2011. Source: Statistics Estonia.

sufficient automatic stabilisers. In general we can say that the government does not have the fiscal tools to smooth cyclical fluctuations.

Additionally, the currency board system restricted the money supply as well as restraining inflation. The central bank does not control inflation in this case and the only tool for controlling the money supply is the reserve requirement rate for commercial banking. However, as all Estonian banks are in fact Scandinavian banks, they do not face any restrictions on borrowing additional finances from Scandinavia during a boom, and therefore their financial ability to increase the money supply did not depend on their current reserves.

In such a situation a flexible labour market appears to be an institution for macroeconomic adjustment. Compared to those in other EU member states, the Estonian labour market is considered to be very flexible. Although employment protection legislation (EPL) shows that Estonia has a relatively rigid labour market, a broader approach observing several different aspects of labour market flexibility reveals the opposite. Even though the employment protection index in Estonia is relatively high, the job destruction and job creation rates are very high as well. This may result from weak law enforcement, but it is more probable that the low administrative capacity of state institutions and trade unions may explain the situation. Unemployment data from the crisis also prove the flexibility of the labour market. Within a year unemployment escalated from $4 \%$ to almost $20 \%$ and average nominal wages declined by more than $10 \%$ in 2009 .

Some labour market institutions were created quite late in Estonia. For instance the unemployment insurance system started to operate eleven years after the first unemployed people were reported to the National Labour Market Board. Trade unions are relatively weak and there are several sectors where unions do not exist. Expenditures on active labour policies in Estonia are among the lowest in the EU and the unemployment allowance is very low at $23 \%$ of the national minimum wage. Unemployment insurance benefit is higher at 50\% of the earlier salary for the first 100 days, but only $25 \%$ of the registered unemployed are covered. It can 
even be said that the institutionalisation of the Estonia labour market is relatively low, although low institutionalisation equally means high flexibility of labour market.

Labour market reform was launched in 2009 in Estonia. There were two sides in this reform. Firstly, new labour Law Contract Act was amended. The new Act enabled more flexibility in labour relations, severance payments and the notice time was reduced. In general it could be said that termination of employment relations became less expensive for employers. Secondly, the institutional reform merged National Labour Market Board and Unemployment Insurance Fund.

Empirical results do not show clear evidence of the effectiveness of legislative reforms. Centre of Policy studies Praxis carried out a large survey among employers and employees in 2012 (Praxis, 2013). According to their report the reduction in lay-off payments did not seem to have any significant impact on the lay-off behaviour of employers. According to their survey, only a small proportion of employers said that they would have laid off fewer employees if the previous act had remained in force. These results were also confirmed by data from the Tax and Customs Board, in which the impact of reducing lay-off payments was assessed according to lay-off probability and on the basis of which a significant impact of the reform on lay-off behaviour could not be identified. Thus, the reform has left employers with more money for other costs incurred in lay-off situations, but this has not led to any more lay-offs than in the case of the old act. When placing this in the context of the financial crisis, it must be said that the Employment Contracts Act entered into force at a time when most lay-offs had already taken effect (Praxis, 2013).

All in all, it can be said that the labour market reacted to the economic crisis quickly and very flexibly. The measures taken, included a reduction of working time and wages and redundancies among employees. This indicates that the traditional institutional factors that protect workers and also increase the inflexibility of the labour market, such as labour market regulation or trade unions, are not very strong in Estonia and do not have a significant effect on the flexibility of the labour market. The situation may also be affected by the fact that even when there are regulations in force, they are often ignored or as it was said in the previous paragraph, some policy measures were taken but they were introduced too late, as changes in the labour market had already taken place.

\section{Endnotes}

${ }^{1}$ The major institutional changes also took place in 2009, see for details next sub-chapter.

${ }^{2}$ For details please see next sub-chapter.

${ }^{3}$ In Estonia only the registered unemployed are eligible, while elsewhere the employed who are at risk of involuntary job loss and inactive persons who would like to enter the labour market are also covered.

${ }^{4}$ In 2009 it was associated with Unemployment Insurance Fund, more details in next sub-chapter.

${ }^{5}$ Public sector means here both state-funded institutions and institutions run by local municipalities. Most schools and cultural institutions such as libraries are financed by local budgets.

${ }^{6}$ To assess the severity of the labour market regulations, various indices have been used, the best-known of which are the Organisation for Economic Development and 
Cooperation (OECD) Employment Protection Legislation (EPL) Index, the sub index on the severity of employment laws in the World Bank's Ease of Doing Business Index, and the sub-index for economic freedom indicators in the Heritage Foundation's Index of Economic Freedom.

${ }^{7}$ The exact definitions of the three situations can be found in Statistics Estonia compendiums dealing with ETU methodology, see Statistics Estonia: 2006 Labour Market in Figures.

${ }^{8} \mathrm{~A}$ separate issue is the geographical mobility of the workforce, which is not examined here.

${ }^{9} \mathrm{E}$ for employment, $\mathrm{U}$ for unemployment and I for inactivity.

${ }^{10}$ Before 2000, changes in situation were examined from January to January. As of 2001, movement has been defined as a change in situation compared to the same month of the previous year. Therefore, all the movements for a year are totalled by month and then an average obtained. Arithmetically: average annual movement = total (January-January, February-February, .....)/12.

${ }^{11}$ Worker flows (flows between places of employment and employment status) are related to job flows as follows: the sum of job creation and job destruction gives the maximum amount of worker reallocation induced by the flow of jobs between firms, while the difference between job creation and destruction gives the minimum worker reallocation (Davis and Haltiwanger, 1992).

${ }^{12}$ Under Estonian law this means that workers left their jobs voluntarily and they are not eligible for benefits. There is a lot of anecdotal evidence that these workers were forced to leave by management.

\section{Appendix 1}

Fiscal policy and austerity measures during Great Recession

In 2008, the abrupt deterioration of the economic conjuncture caused the budget deficit of nearly 3\% of GDP. This deficit did not result only from economic recession or lower tax revenues, because during the economic growth, many cost-increasing laws were stipulated and contractual obligations taken. For instance, the budget of pension insurance increased by 8 billion kroons (nearly 70\%) and the budget of Estonian Health Insurance Fund by more than $50 \%$ (4 billion kroons).

As a result Government made the decision to improve the budgetary position (cut expenditures and find extra income) by approximately 20 billion EEK, i.e. over $9 \%$ of GDP. In more details these measures were:

- $10,6 \%$ cut in operational expenditure of the central government

- including the wage bill by $9,6 \%$ and administrative costs by $12 \%$,

- Reduction of the annual pension increase from $14 \%$ (that was foreseen by the relevant regulation before) to $5 \%$,

- Incapacity benefits covered by the Health Insurance Fund are reduced towards more own responsibility of employers (introduction of 3 days company responsibility) and employees (increase of own responsibility to from 1 day to 3 days),

- in addition, incapacity benefit was decreased from $80 \%$ of the salary to $70 \%$ of the salary, 
- Stricter limits on new borrowing by municipalities,

- Suspending contributions to the second pillar pension system for until the end of 2010,

- Postponing investments in the Oil Stockpiling Agency and the Estonian Railways Ltd.

On the other hand, Government also increased tax income:

- Increase in value added tax (from $18 \%$ to $20 \%$ ),

- Increase of $10 \%$ in fuel excise taxes, increase of $5 \%$ in cigarettes and tobacco excise taxes,

- Twice higher taxes on natural gas,

- Considerable increases in different environmental duties - mostly related to the use of natural resources, mining in particular.

Despite the aim of not increasing taxes on labour and income, the increases in unemployment insurance fees have been decided in order to ensure financial sustainability of the Unemployment Insurance Fund

- From the first of June the unemployment insurance fees were increased to 3\%; from the first of July 2009 to $4,2 \%$.

As result the fiscal deficit was only 1,4\% of GDP in 2009, which is one of the lowest in EU.

To conclude we can say that fiscal policy in Estonia tends to be pro-cyclic, and amplify the growth phase during periods of economic boom and intensify the decline during a downturn. As it was mentioned before, from 2004 to 2006 Government increased the budget by $20 \%$ per year. In 2009 about $9 \%$ of Government's budget was cut in order to meet Maastricht budget deficit criteria. It means that during the economic boom Government increased substantially their expenditures and during recession they have reduced public expenditures.

\section{Appendix 2}

For raw data, see Table 5 below.

Table 5 Actually worked weekly working hours, in selected industries and countries

\begin{tabular}{lccccr}
\hline Total & $\mathbf{2 0 0 8}$ & $\mathbf{2 0 0 9}$ & $\mathbf{2 0 1 0}$ & $\mathbf{2 0 1 1}$ & $\mathbf{2 0 1 2}$ \\
\hline European Union (27 countries) & 37.3 & 36.9 & 36.9 & 36.9 & 36.7 \\
Euro area (17 countries) & 36.9 & 36.4 & 36.6 & 36.5 & 36.2 \\
Germany & 35.9 & 35.3 & 35.6 & 35.6 & 35.5 \\
Estonia & 39.1 & 37.6 & 38.4 & 38.6 & 38.3 \\
Latvia & 39.4 & 38.8 & 38.4 & 38.5 & 38.3 \\
Lithuania & 39.2 & 38.6 & 38.4 & 38.3 & 38.0 \\
Manufacturing & 2008 & 2009 & 2010 & 2011 & 2012 \\
European Union (27 countries) & 39.2 & 38.4 & 38.9 & 39.0 & 38.7 \\
Euro area (17 countries) & 38.7 & 37.8 & 38.3 & 38.5 & 38.2 \\
Germany & 38.1 & 36.8 & 37.7 & 38.0 & 37.8
\end{tabular}


Table 5 Actually worked weekly working hours, in selected industries and countries (Continued)

\begin{tabular}{|c|c|c|c|c|c|}
\hline Estonia & 39.5 & 37.6 & 38.9 & 39.6 & 39.1 \\
\hline Latvia & 39.0 & 38.7 & 38.8 & 39.3 & 39.1 \\
\hline Lithuania & 39.9 & 39.3 & 39.3 & 39.1 & 39.2 \\
\hline Construction & 2008 & 2009 & 2010 & 2011 & 2012 \\
\hline European Union (27 countries) & 40.6 & 40.2 & 40.1 & 40.1 & 39.9 \\
\hline Euro area (17 countries) & 39.9 & 39.4 & 39.4 & 39.5 & 39.1 \\
\hline Germany & 39.8 & 39.4 & 39.4 & 39.6 & 39.6 \\
\hline Estonia & 40.3 & 38.0 & 39.9 & 40.4 & 40.6 \\
\hline Latvia & 41.4 & 39.1 & 39.0 & 39.1 & 39.1 \\
\hline Lithuania & 40.6 & 39.6 & 39.3 & 39.5 & 39.2 \\
\hline Trade & 2008 & 2009 & 2010 & 2011 & 2012 \\
\hline European Union (27 countries) & 37.4 & 37.1 & 37.1 & 36.9 & 36.8 \\
\hline Euro area (17 countries) & 37.3 & 37.0 & 37.1 & 36.9 & 36.7 \\
\hline Germany & 34.4 & 34.1 & 34.2 & 34.1 & 34.1 \\
\hline Estonia & 39.7 & 38.3 & 39.1 & 39.2 & 38.7 \\
\hline Latvia & 40.2 & 39.7 & 38.8 & 38.6 & 38.2 \\
\hline Lithuania & 39.5 & 39.2 & 39.1 & 38.7 & 38.3 \\
\hline Hotels & 2008 & 2009 & 2010 & 2011 & 2012 \\
\hline European Union (27 countries) & 38.3 & 37.5 & 37.4 & 37.0 & 36.5 \\
\hline Euro area (17 countries) & 39.2 & 38.4 & 38.2 & 37.9 & 37.4 \\
\hline Germany & 34.3 & 33.6 & 33.8 & 33.5 & 33.2 \\
\hline Estonia & 40.0 & 37.5 & 37.7 & 37.3 & 35.7 \\
\hline Latvia & 39.9 & 39.5 & 39.2 & 38.5 & 38.5 \\
\hline Lithuania & 39.3 & 39.2 & 38.7 & 38.3 & 36.9 \\
\hline Public administration & 2008 & 2009 & 2010 & 2011 & 2012 \\
\hline European Union (27 countries) & 36.8 & 36.7 & 36.8 & 36.7 & 36.8 \\
\hline Euro area (17 countries) & 36.2 & 36.1 & 36.2 & 36.3 & 36.3 \\
\hline Germany & 37.1 & 36.7 & 36.8 & 36.9 & 36.9 \\
\hline Estonia & 39.4 & 39.2 & 40.4 & 39.8 & 39.3 \\
\hline Latvia & 39.0 & 39.1 & 39.5 & 39.6 & 39.1 \\
\hline Lithuania & 40.0 & 39.9 & 40.2 & 40.2 & 40.0 \\
\hline
\end{tabular}

Source: Eurostat database.

Competing interests

The IZA Journal of European Labor Studies is committed to the IZA Guiding Principles of Research Integrity. The author declares that he has observed these principles.

Acknowledgements

This paper was supported by IZA and CESifo institute who offered financial support and their excellent working environment during the final state of finishing the paper.

Responsible editor: Martin Kahanec

Received: 15 March 2013 Accepted: 20 May 2013

Published: 18 June 2013

References

Arro R, Eamets R, Järve J, Kallaste E, Philips K (2001) Labour market flexibility and employment security - Estonia,

Employment paper No. 25. International Labour Organization, Geneva, p 85

Babecky J (2008) Aggregate wage flexibility in the new EU member states. AUCO Czech economic. Review 2(2):14-123 
Berengaut J, Garibaldi P, Jones D, Le Gall F, Psalida E, Schiff J, Stern R, Westin K, López-Claros A (1998) The Baltic countries: from economic stabilization to EU accession. International monetary fund, occasional paper no 173, p 87

Boeri T, Garibaldi P (2007) Two tier reforms of employment protection: a honeymoon effect? Econ J Royal Econ Soc 117(521):357-385

Brixiova Z, Egert B (2012) Labour market reforms and outcomes in Estonia, comparative economic studies. Palgrave Macmillan 54(1):103-120

Castrén O, Takalo T, Wood G (2004) Labour market reform and the sustainability of exchange rate pegs working paper series 406. European Central Bank. http://www.ecb.int/pub/pdf/scpwps/ecbwp406.pdf

Cazes S, Nesporova A (2004) Labour markets in transition: balancing flexibility and security in Central and Eastern Europe. Revue de l'OFCE 5:23-54

Chassard Y (2001) Social dialogue in estonia. Study commissioned by the EuropeanSocial partners. ETUC/UNICE-UEAPME/CEEP

Cuestas JC, Gil-Alana LA, Staehr K (2011) A further investigation of unemployment persistence in European transition economies. J Comp Econ 39(4):514-532

Davis SJ, Haltiwanger JC (1992) Gross job creation, gross job destruction and employment reallocation. Quarterly J Econ 107(3):819-863

Eamets R (2000) Reallocation of Labour during Transition. Disequilibrium and Policy Issues. The Case of Estonia. Dissertatsiones Rerum Oeconomicarum Universitatis Tartuensis (PhD Thesis in Economics), No 5, Tartu University Press, $\mathrm{p} 252$

Eamets R (2012) Labour Market in Estonia: Responding to the Global Finance Crisis. CESifo DICE Report 10(2):34-39

Eamets R, Leetmaa R (2008) Labour market and labour policy, Estonian human development report 2008. Eesti Koostöö Kogu, Tallinn, pp 138-147

Eamets R, Masso J (2005) Labour market flexibility and employment protection regulation in the Baltic states. European J Indus Relat 11(1):71-90

Eamets R, Paas T (2007) Labour market flexibility. In: Paas T, Eamets R (ed) Flexicurity and employment. Nova Science, New York, pp 183-186

Estonian Human Development Report 2008 (2009). Eesti Koostöö Kogu, Tallinn, p 177

Expenditure on Labour Market Policies (2008) CESifo DICE report 3/2008. http://www.cesifo-group.de/de/ifoHome/ publications/journals/CESifo-DICE-Report/Archiv/CESifo-DICE-Report-2008.html

Feuerstein S, Grimm O (2006) On the credibility of currency boards. Rev Inter Econ 14:818-835

Gilson C (2002) Policy Pre-commitment and institutional design: a synthetic indicator applied to currency boards. OECD Economics Department Working Paper No 330, OECD. http:/www.oecd-library.org/docserver/download/ 5lgsjhvj7zkj.pdf?expires=1371721821\&id=id\&accname=guest\&checksum=FDB693D170EA4C962ABB321F87C1B6C3

Haltiwanger J, Lehmann H, Terrell K (2003) Job creation and Job destruction in transition countries. Econ Trans 11(2):205-219

Health (2008) Labour and social sector in 2007. Ministry of Social Affairs, Tallinn, p 112

Kattel R, Raudla R (2012) Austerity that never was? The Baltic states and the crisis. Policy Note/Levy Economics Institute of Bard College. http://www.levyinstitute.org/pubs/pn_12_05.pdf

Lauringson A (2011) Disincentive effects of unemployment insurance benefits: maximum benefit duration versus benefit level. Baltic J Econ 11(1):25-50

Lauringson A (2012) The impact of the generosity of unemployment benefits on Estonian labour market outcomes in a period of crisis dissertationes rerum oeconomicarum universitatis tartuensis, No 44. Tartu University Press, Tartu

Leetmaa R, Võrk A, Eamets R, Sõstra K (2003) Aktiivse tööpoliitika tulemuslikkuse analüüs Eestis. Poliitikauuringute Keskus PRAXIS, Tallinn, p 108

Lehmann H, Muravyev A (2012) Labor market institutions and labor market performance: what can we learn from transition countries? Econ Trans 20(2):235-269

Malk L (2012) Töölepingu seaduse roll turvalise paindlikkuse kujunemisel Eestis, magistritöö. Tallinna Tehnikaülikool, Tallinn

Masso J, Krillo K (2011) Mixed adjustment forms and inequality effects in Estonia, Latvia and Lithuania in work inequalities in the crises D. In: Edward E (ed) Vaughan-whitehead. ILO, pp 38-102

Masso J, Eamets R, Philips K (2007) Creative destruction and transition: evidence on firm demographic from Estonia. In: Arauzo JM, Manjón M (ed) Entrepreneurship, industrial location and economic growth. Edward Elgar Publishing, pp 81-103

Moheeput A (2008) Issues on the choice of exchange rate regimes and currency boards - an analytical survey. Warwick Economic Research Papers, p 855. http://www2.warwick.ac.uk/fac/soc/economics/research/workingpapers/2008/twerp_855.pdf

Praxis (2013) Töölepingu seaduse uuring, Praxis, Centar. Turuuuringute AS, Tallinn

Rõõm T, Dabušinskas A (2011) How wages respond to shocks. Asymmetry in the speed of adjustment. European Central Bank, WDN Working Paper series No 1340

Room T, Uuskula L (2009) The principles of wage formation in Estonian companies. In: Mayes DG (ed) Microfoundations of economic success: lessons from Estonia. Edward Elgar. Publishing, Cheltenham, UK

Semerák V, Švejnar J (2009) New member countries' labour markets during the crisis. BEPA Societal Brief. http://idea. cerge-ei.cz/documents/studie_2009_01_Unemployment.pdf

Tööturuameti maine uuring 2008 (2008) Aruanne. Turu-uuringute AS, Tallinn. 350 lk

Töövaldkonna areng 2007 (2008) In: Marksoo U (ed) Sotsiaalministeeriumi toimetised nr 5/2008. Sotsiaalministeerium 2008, p 46

doi:10.1186/2193-9012-2-4

Cite this article as: Eamets: Labour market and labour market policies during great recession: the case of Estonia.

IZA Journal of European Labor Studies 2013 2:4. 